\title{
Protein Patched Homolog 1
}

National Cancer Institute

\section{Source}

National Cancer Institute. Protein Patched Homolog 1. NCI Thesaurus. Code C18605.

Protein patched homolog 1 (1447 aa, $161 \mathrm{kDa}$ ) is encoded by the human PT CH1 gene.

This protein is involved in the modulation of hedgehog protein family signaling pathways, embryonic development, and tumor supression. 